\begin{tabular}{|c|c|c|c|c|c|c|}
\hline \multirow{3}{*}{$\begin{array}{l}\text { 2. ECN Category } \\
\text { (mark one) } \\
\text { Supplemental } \\
\text { Difect Revision } \\
\text { Change ECN } \\
\text { Temporary } \\
\text { Standby } \\
\text { Supersedure } \\
\text { Cancel/Void }\end{array}$} & \multirow{3}{*}{$\begin{array}{r}{[]} \\
{[X]} \\
{[]} \\
{[]} \\
{[]} \\
{[]} \\
{[]}\end{array}$} & \multicolumn{2}{|c|}{$\begin{array}{l}\text { 3. Originator's Name, Organization, MSIN, } \\
\text { and Telephone No. } \\
\text { Danny Mendoza, 74E50, H5-09, } \\
\text { 372-1071 }\end{array}$} & \multicolumn{2}{|c|}{$\begin{array}{l}\text { 3a. USQ Required? } \\
\text { [] Yes }[X] \text { No }\end{array}$} & $5 / 14 / 96$ \\
\hline & & \multicolumn{2}{|c|}{$\begin{array}{l}\text { 5. Project Title/No./Work Order No. } \\
\text { Baseline Comparison Report for Project } \\
\text { W-058, Replacement of the Cross-Site } \\
\text { Transfer System/ } W-058\end{array}$} & \multicolumn{2}{|c|}{$\begin{array}{l}\text { 6. Bidg./Sys./Fac. No. } \\
\text { Cross-Site } \\
\text { Transfer System }\end{array}$} & $\begin{array}{c}\text { 7. Approval Designator } \\
\text { N/A }\end{array}$ \\
\hline & & \multicolumn{2}{|c|}{$\begin{array}{l}\text { 8. Document Numbers Changed by this ECN } \\
\text { (includes sheet no. and rev.) } \\
\text { WHC-SD-W058-RPT-002, Rev. } 1\end{array}$} & \multicolumn{2}{|c|}{$\begin{array}{l}\text { 9. Related ECN No(s). } \\
\qquad N / A\end{array}$} & $\begin{array}{l}\text { 10. Related PO No. } \\
\qquad N / A\end{array}$ \\
\hline \multirow{2}{*}{\multicolumn{2}{|c|}{$\begin{array}{l}\text { 11a. Modification Work } \\
{[] \text { Yes (fill out Blk. }} \\
11 \mathrm{~b} \text { ) } \\
{[X] \text { No (NA Blks. 11b, }} \\
11 \mathrm{c}, 11 \mathrm{~d} \text { ) }\end{array}$}} & \multirow[t]{2}{*}{$\begin{array}{l}\text { 11b. Work Package } \\
\text { No. } \\
\text { N/A }\end{array}$} & \multicolumn{2}{|c|}{$\begin{array}{l}\text { 11c. Modification Work Complete } \\
\text { N/A }\end{array}$} & \multicolumn{2}{|c|}{$\begin{array}{l}\text { 11d. Restored to Original Condi- } \\
\text { tion (Temp. or Standby ECN only) } \\
\text { N/A }\end{array}$} \\
\hline & & & \multicolumn{2}{|c|}{ Cog. Engineer Signature \& Date } & \multicolumn{2}{|c|}{ Cog. Engineer Signature \& Date } \\
\hline
\end{tabular}

12. Description of Change

The attached document replaces WHC-SD-W058-RPT-002, Rev. 1 in its entirety. Text in Section 1.1 was added to clarify that transfer requirements for waste retrieval and processing will have to be continually evaluated as part of the systems engineering process to assure that the architecture is in place to satisfy these requirements. Text was added in Section 2.1 to clarify that there is currently no method of transferring highly radioactive waste from 200 West to 200 East that meets current safety and regulatory requirements. Text was added to Section 4.0 to clarify that the current requirements for transfer waste meet and/or exceed the requirements for Transfer Manage Tank Waste and will accommodate the requirements currently identified for the retrieval and processing of the waste. Also clarified in this section was the fact that an alternatives evaluation had been performed and pipeline was the preferred alternative. Section 5.0, Reference Section, was updated.

13a. Justification (mark one)

\begin{tabular}{llllllll} 
Criteria Change & [] & Design Improvement & [] & Environmental & [] & Facitity Deactivation [] \\
As-Found & [] & Facilitate Const & [] & Const. Error/Omission & [] & Design Error/Omission \\
\hline
\end{tabular}

13b. Justification Details

DOE $H Q$ had reviewed Rev. 1 and provided comments. WHC and DOE RL agreed to the comments, provided resolution and incorporated them by making the above mentioned changes.

14. Distribution (include name, MSIN, and no. of copies) See Distribution Sheet

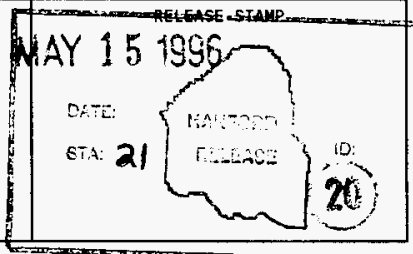

A-7900-013-2(11/94) GEF095 


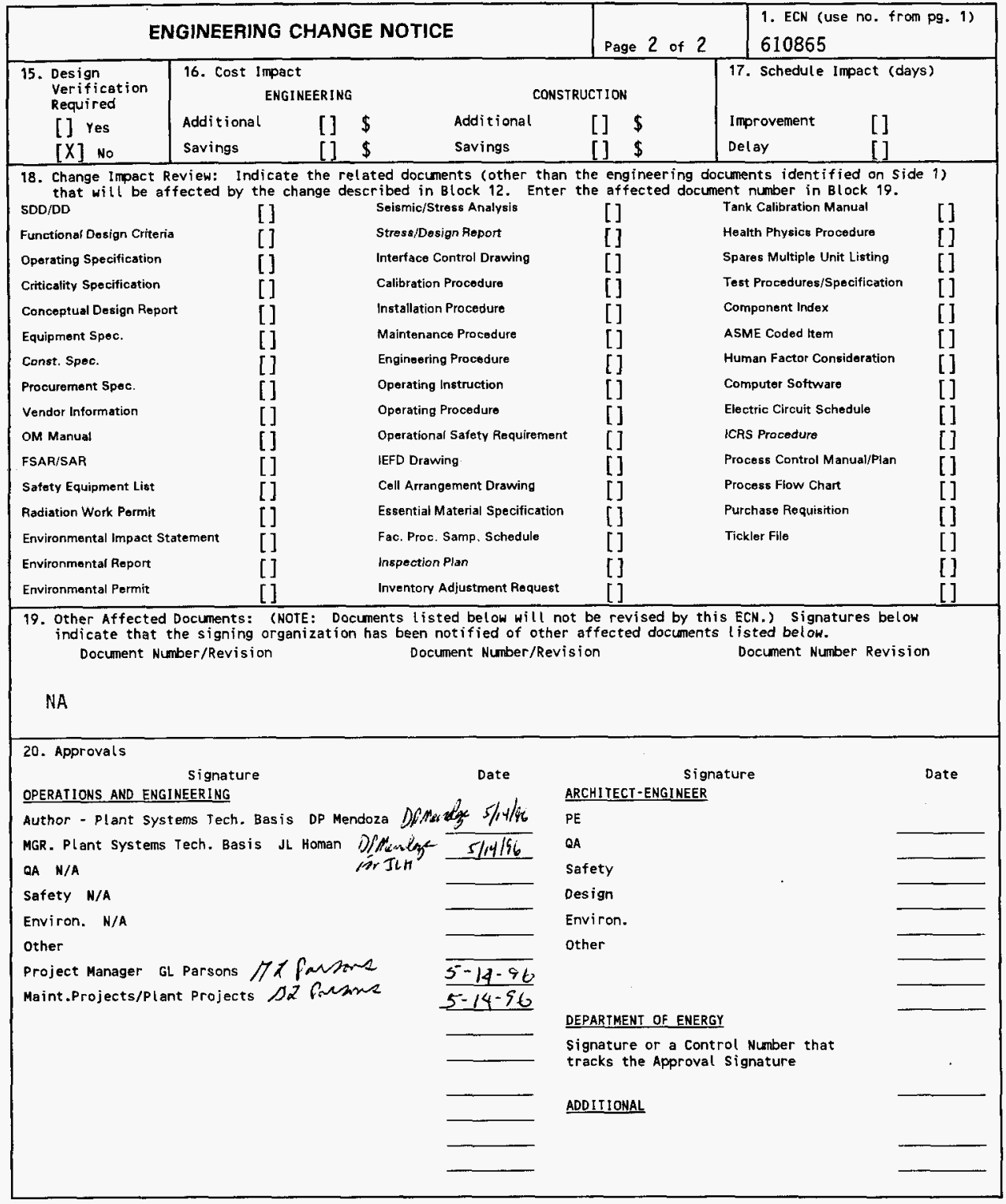




\section{Baseline Comparison Report for Project W-058, Replacement of the Cross-Site Transfer System}

Danny P. Mendoza

West inghouse Hanford Company, Richland, WA 99352

U.S. Department of Energy Contract DE-AC06-87RL10930

EDT/ECN: $610865 \quad$ UC: 2030

Org Code: 74E50 Charge Code: N58MB

B\&R Code: EW3130010 Total Pages: 28

Key Words: Design Requirements Document, Functional Design Criteria, Baseline Comparison, Cross-Site Transfer

Abstract: This BCR compares the Project W-058 Functional Design

Criteria with the Project W-058 Preliminary Design Requirements

Document, and identifies the differences between the two documents in the mission definition, project requirements, system functions, and interfaces. Impacts these differences have on current project design are also discussed.

TRADEMARK DISCLAIMER. Reference herein to any specific comercial product, process, or service by trade name, trademark, manufacturer, or otherwise, does not necessarily constitute or imply its endorsement, recommendation, or favoring by the United States Government or any agency thereof or its contractors or subcontractors.

Printed in the United States of America. To obtain copies of this document, contact: WHC/BCS Document Control Services, P.0. Box 1970, Mailstop H6-08, Richland WA 99352, Phone (509) 372-2420; Fax (509) 376-4989.

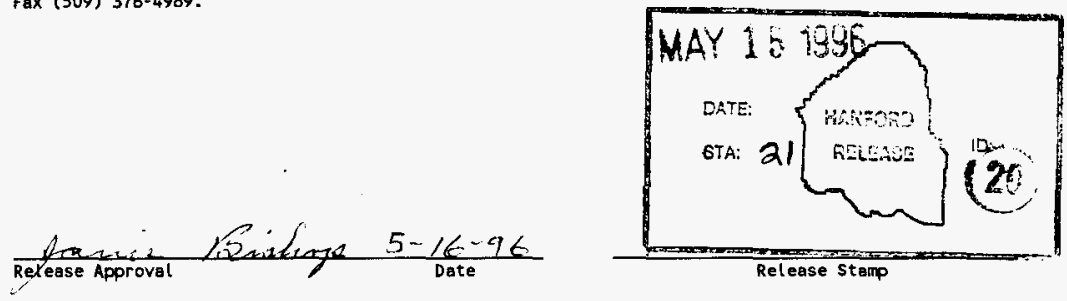

\section{Approved for Public Release}




\section{RECORD OF REVISION}
(1) Document Number
WHC-SD-W058-RPT- 002

(2) Title

Baseline Comparison Report for Project W-058, Replacement of the Cross-Site Transfer System

CHANGE CONTROL RECORO

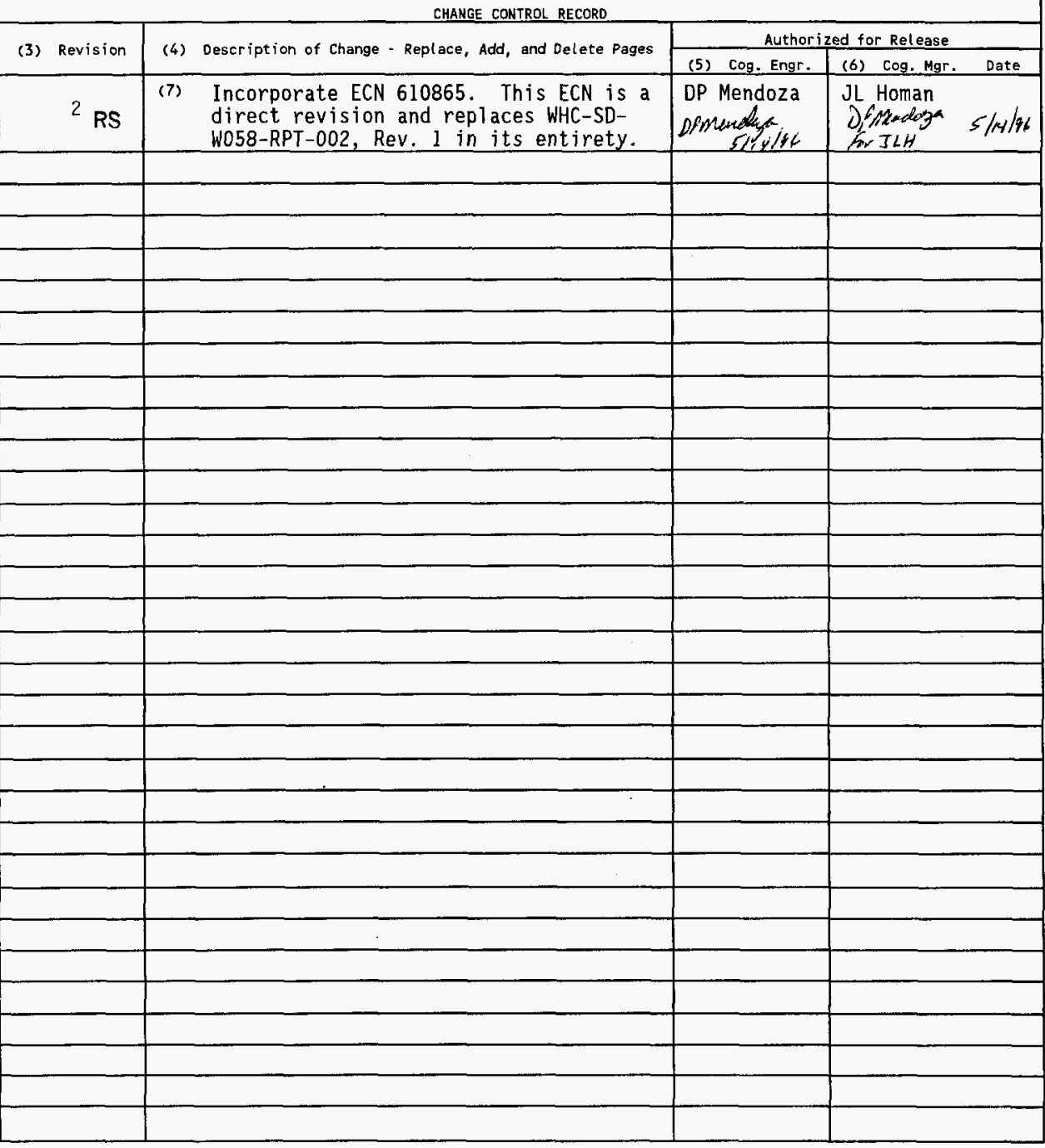


WHC-SD-W058-RPT-002, Rev. 2

BASELINE COMPARISON REPORT

FOR

PROJECT W-058

REPLACEMENT OF THE CROSS-SITE TRANSFER SYSTEM

Prepared for

U. S. Department of Energy Richland Field office

Richland, Washington

by

Westinghouse Hanford Company

Richland, Washington 99352 
WHC-SD-W058-RPT-002, Rev. 2

This page intentionally left blank. 


\section{EXECUTIVE SUMMARY}

In response to the Defense Nuclear Safety Board's 92-4 Recommendations, the U.S. Department of Energy developed the 92-4 Implementation Plan (DOE/RL94-115) which outlined the approach for implementing systems engineering to the TWRS Program in order to satisfy these recommendations. This 92-4 Implementation Plan committed that systems engineering would be implemented for all projects, new as well as existing, in order to provide technical justification and traceability for project functions, requirements and architecture selection. Project $W-058$, Replacement of the Cross-Site Transfer System, utilized a graded approach appropriate in implementing systems engineering because upper level TWRS systems engineering analysis and documentation had not been fully developed. This approach included the development of a Preliminary Design Requirements Document (PDRD) and the comparison of its functions and requirements against the current Project Functional Design Criteria (FDC) document for the project. This comparison is documented in the following report.

The report highlighted five areas in which significant differences were found between the PDRD and the FDC. These areas included definition of the cross-site transfer function, total waste volume and yearly peak flow rate requirements, shielding requirements, design life requirements, and requirements that were developed in the PDRD but not specifically called out in the FDC.

It was concluded that the differences between the PDRD and the project design baseline document (FDC) had little or no impact on the current project design, and a change to the existing baseline was not warranted. 
WHC-SD-W058-RPT-002, Rev. 2

This page intentionally left blank. 


\section{TABLE OF CONTENTS}

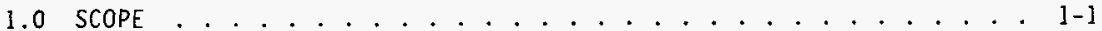

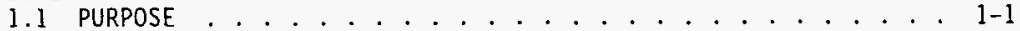

1.2 BACKGROUND ....................... . . . . . . .

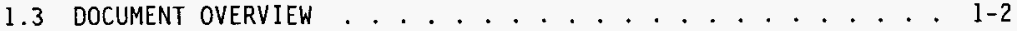

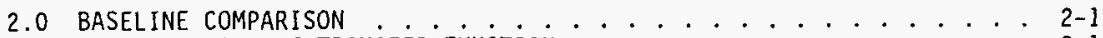

2.1 CROSS-SITE TRANSFER FUNCTION . . . . . . . . . . 2-1

2.1.1 Function Definition - PORD . . . . . . . . 2-2

2.1.2 Function Definition - FDC .......... 2-2

2.1.3 Cross-Site Transfer Function Difference . . . . 2-3

2.1.4 Impacts to Project Resulting From Function Definition

Differences. . . . . . . . . . 2-3

2.2 CROSS-SITE TRANSFER REQUIREMENTS . . . . . . . . . 2-4

2.2.1 Waste Volume Requirements . . . . . . . . 2-4

2.2.1.1 Total Waste Volumes - PDRD. . . . . . . 2-4

2.2.1.2 Total Waste Volumes - FDC. . . . . . . . 2-4

2.2.1.3 Total Waste Volumes Differences. ...... 2-4

2.2.1.4 Impacts to Project Resulting From Waste

Volume Differences. . . . . . . . . 2-5

2.2.2 Shielding Requirements . . . . . . . . . 2-5

2.2.2.1 Shielding Requirements - PORD. ..... 2-5

2.2.2.2 Shielding Requirements - FDC. ...... 2-6

2.2.2.3 Shielding Requirements Differences. .... 2-6

2.2.2.4 Impacts to Project Resulting From Shielding

Difference. . . . . . 2- 2-6

2.2.3 Design Life Requirements . . . . . . . . . . . . 2-6

2.2.3.1 Design Life - PDRD. . . . . . . . . . 2-6

2.2.3.2 Design Life - FDC.......... . . 2-7

2.2.3.3 Design Life Differences. . . . . . . 2-7

2.2.3.4 Impacts to Project Resulting From Design Life

Differences. . . . . . . . 2-7

2.2.4 PDRD Requirements Not Included in FDC . . . . 2-7

2.2.4.1 Mean Time Between Failure. . . . . . . . 2-8

2.2 .4 .2 Availability. . . . . . . . 2-8

2.2.4.3 Excess Facilities Interface Requirements. . . 2-8

2.2.4.4 Maintenance. . . . . . . . . . 2-8

2.2.4.5 Transportation of Hazardous Materials. . . . 2-9

3.0. EXISTING SYSTEM INTERFACE ..................... . . . .

3.1 CURRENT SCOPE OF W-058 ................ 3-1

3.2 OTHER PROJECTS/EXISTING ARCHITECTURES ......... 3-1

3.2.1 Tank Farms Restoration and Safe Operations, W-314 . . 3-1

3.2.2 SY-Farm Existing Architecture ......... . 3-1

3.2.2.1 Transfer System. . . . . . . . . . . . . 3-1

3.2.2.2 Flushing System. .......... 3-2

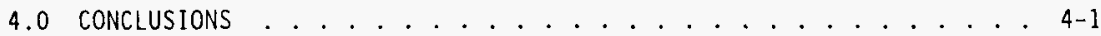

5.0 REFERENCES ..................... . . . . . 
WHC-SD-W058-RPT-002, Rev. 2

\section{FIGURES}

FIGURE 3.1-1 Current Scope - Project $W-058$............. . 3-3 


\subsection{SCOPE}

\subsection{PURPOSE}

The purpose of this Baseline Comparison Report (BCR) is to provide systems engineering validation that the design criteria documented in the Project W-058 Functional Design Criteria (WHC, 1995a) are technically sound. This will be accomplished by comparing the requirements captured in this project design base?ine document to those developed in the Preliminary Design Requirements Document (WHC, 1995b) at the level at which project scope can be identified. It is also intended to determine the adequacy of the Project W-058 system architecture in satisfying the scope and performance of the cross-site transfer function as identified by the program analyses and documented in the project Preliminary Design Requirements Document (PDRD). The current issue of the PDRD does not include requirements pertaining to the retrieval and processing of tank waste as the requirements analys is is not yet complete. Transfer requirements for waste processing and retrieval will have to be continually evaluated as part of the systems engineering process to assure the architecture is in place that would satisfy these needs.

\subsection{BACKGROUND}

In 1992, the Defense Nuclear Facilities Safety Board (DNFSB) performed a project review for the Multi-Function Waste Tank Facility (MWTF). The DNFSB recommended that the U.S. Department of Energy (DOE) should ident ify the design bases and engineering principles and approaches that provide data and rationale to show that the design for the MWTF conservatively meets the quantitative safety goals described in the Department's Nuclear Safety Policy (SEN-35-91). This was documented in the DNFSB's 92-4 Recommendations. In light of the DNFSB's comments, the DOE reconsidered its overall approach to cleaning up the Hanford Site by interpreting the DNFSB's recommendations on a broader scale. In response to the 92-4 Recommendations, the DOE developed DOE/RL-94-115, 92-4 Implementation Plan, which out lined the approach for implementing systems engineering to the TWRS Program and would satisfy the above mentioned recommendation. The systems engineering approach would be implemented for all projects, new as well as existing, and would provide technical justification and traceability for project functions, requirements and architecture selection. To incorporate this process into ongoing projects, a design requirements document (DRD) would be developed and provided for each of the projects. The existing project baseline documentation would then be compared to the DRD to determine if the project satisfied the functions and requirements identified by the program analyses. The comparison and the results would be documented in the project BCR.

It was determined for Project $W-058$ that a graded approach appropriate to the current project status would be applied since upper level TWRS systems engineering analysis and documentation was not fully developed (Riesenweber, 1995a). This approach included the development of a PDRD and the comparison of the functions and requirements to the current Project Functional Design Criteria (FDC) document, with the results documented in the $B C R$. 


\subsection{DOCUNENT OVERVIEW}

This BCR compares the Project $W-058$ Functional Design Criteria against the Project W-058 Preliminary Design Requirements Document, and documents the significant differences in the mission definition, project requirements, system functions, and interfaces found. Areas where differences have been identified in the FDC and the PDRD are discussed in Section 2.0. A description of the area in question from both perspectives is provided, with difference being described, as well a summary of any impacts these differences may have on the current project path.

Some of the differences noted between the FDC and the PDRD while performing the baseline comparison are not appropriate to list in this report based on the following reasons. Some of these differences occurred because the two documents have different formats and serve different purposes for the project. The PDRD is intended to be developed early in the project cycle to define project scope and boundaries at a high level, while the FDC provides more detailed design requirements as the project evolves. The FDC therefore includes requirements that are not included in the PDRD, but which may be applicable if the systems engineering process were continued to the level of detail appropriate to the FDC.

TWRS Systems Engineering issued guidance on the format of the PDRD (Peck, 1995). Based on this format, specific sections of the PDRD required more detail in a particular area of requirements. The FDC addressed these same details, but in a general format by listing the source of the requirements in Section 7.0, Codes and Standards. This section 1ists the regulations, codes, and standards for project compliance. In some cases, criteria differences are not listed in this report because they were attributed to the writing styles of the authors and not to any significant difference in the requirements. 


\subsection{BASELINE COMPARISON}

\subsection{CROSS-SITE TRANSFER FUNCTION}

The need for the transfer of waste cross-site can be defined by two subfunctions based on the current program analyses. The first need is to support the management of the waste located in the 200 West Area Tanks, which can be defined as a near term need. The second will likely be to support the movement of waste cross-site during the retrieval and processing phase of this waste, which can be defined as a long term need. The processing phase is defined as the pretreatment and immobilization of this waste.

The transfer of wastes cross-site is necessary for the management of tank waste volumes in the 200 West Area Double Shell Tanks (DSTs). Tank 241-SY-102 is the staging tank for transfers of waste from 200 West to the 200 East Area. The cross-site transfer of this 1 iquid wastes will create needed space in tank 241-SY-102 for receipt of Single Shell Tank (SST) supernatant, waste generated from PFP stabilization activities, and waste from terminal cleanout of the S-Labs and T-Plant. It will also allow for maintaining emergency spare capacity in the West Area in the event of a leaking tank by providing the capability to move wastes out of the 200 West Area DSTs, thus providing space. Current space available in the 241-SY-102 tank is $1.43 \times 10^{6}$ L (378 Kgal) (Hanlon, 1995)'.

The mission of the SST interim stabilization program is to recover and transfer the pumpable liquid waste remaining in the 200 Area SSTs. The pumpable liquids remaining in the West Area SSTs will be sent to a designated 200 West Area DST (241-SY-102 for non-complexed waste). The Hanford Federal Facility Agreement and Consent Order, TPA M-41-00, "Complete Single Shell Tank Interim Stabilization", outlines the timeframe for completion of the interim stabilization program. Intended completion is by September 30, 2000. The current volume projected for pumpable liquid waste remaining in the 200 West Area SSTs is $1.36 \times 10^{7} \mathrm{~L}(3.58 \mathrm{Mgal})$ (Hanlon, 1995).

Additional waste volumes projected will be generated from T-Plant, PFP, and S-Lab (WHC 1994a). This waste, combined with the SST interim stabilization projected volume and the liquid waste that currently exists in tank 241-SY-102, totals $3.63 \times 10^{7} \mathrm{~L}(9.59 \mathrm{Mgal})$. The cross-site transfer system and the interfacing systems shall be capable of transferring a minimum of this volume of liquid waste.

The need for tank space to accommodate a leaking tank comes from $D O E$ Order 5820.2A, Chapter I, Section 3.b(4)(d) which states:

"For emergency situations involving liquid high-level waste, spare capacity with adequate heat dissipation capability shall be maintained to receive the largest volume of liquid contained in any one tank. Adequate transfer pipelines also shall be maintained in operational condition. Interconnected tank farms with adequate transfer capabilities and spare capacity may be 


\section{considered as a single tank farm for purposes of this requirement."}

This operational constraint will be enforceable in the West Area tank farms as long as there is high level waste stored in these tanks.

The transfer of wastes cross-site may be necessary for the processing of tank wastes in both the West Area and the East Area. Once decisions are made on the methods for retrieval, pretreatment, and immobilization, and the performance requirements associated with these programs are developed and refined, design requirements can then be imposed on the cross-site Transfer System (CSTS) to satisfy this portion of the cross-site transfer function.

Features in the current design, such as the ability to transfer solids in the CSTS, support both the management of tank waste and processing of tank waste and are anticipated to be sufficient for the treatment and disposal functions.

There is currently no architecture or method of transferring high-level radioactive and mixed waste from the 200 West Area to the 200 East Area which is compliant to the current safety and regulatory requirements that would satisfy the above functionality and its associated requirements as documented in the project PDRD (WHC, 1995b). The existing cross-site transfer system has exceeded its original design life and the reliability is not favorable. of the six original cross-site transfer lines, four have failed. One of the remaining two has been pressure tested and used to successfully transfer 435,400 gallons of waste from 241-SY-102 to 241-AP-104. The reliability of this single line for a 10 year mission has been analyzed to be $2.8 \%$. The reliability of both of the remaining lines over the 10 year mission is $16 \%$ (Coles, 1995).

\subsubsection{Function Definition - PDRD}

The primary function of the CSTS, as defined by the PDRD, is to support the transfer of liquid and slurry wastes that require no prior conditioning or mobilization from Tank 241-SY-102 in the 200 West Area to the storage facilities (DSTs) located in the 200 East Area. Such transfers serve the purpose of managing tank waste volumes and tank space in the 200 West Area DSTs, a near term need. Although it is anticipated that the future mission of retrieval/processing will have a need for the transfer of waste, this need nor any requirements associated for this need are not defined in the PDRD as the requirements for waste retrieval and processing have not been fully developed.

\subsubsection{Function Definition - FDC}

The primary function of the Replacement of the Cross-Site Transfer System (RCSTS), as defined by the Project FDC, is to transfer liquid waste, slurry, and raw water flush between the SY Tank Farm in the 200 West Area and the 200 East Area Tank Farms. The system provides for west-to-east transfers and can be configured for east-to-west transfers in support of future TWRS activities. The system also facilitates future connection for all applicable TWRS facilities. 


\subsubsection{Cross-Site Transfer Function Difference}

Section 2.1 above identifies the need and the basis for the management of the tank space in the 200 West Area and the movement of waste cross-site to storage facilities in the 200 East Area. The requirements associated with this waste movement are known and documented in the Project PDRD. The location and performance requirements (i.e., waste volumes, feed characteristics, etc.) of future immobilization and pretreatment facilities have not been fully defined and, therefore, design requirements to support waste processing cannot be appropriately levied on the CSTS design.

Requirements for waste processing (retrieval, pretreatment, and immobilization) need further development before adequate design requirements can be levied on the CSTS. The difference in the two functions is that the PDRD does not explicitly define as part of the CSTS function the support of processing waste. The FDC does define the CSTS as having some capability to support the retrieval and processing of the wastes.

In summary, the FDC defines the CSTS function as one that will facilitate future retrieval and processing functions and requirements even though, to date, requirements for these functions are not fully developed. The PDRD does not define the CSTS function as supporting retrieval and processing functions as these requirements, again, are not fully developed and, therefore, cannot be levied on the system design via the PDRD.

\subsubsection{Impacts to Project Resulting From Function Definition Differences.}

Although the current functional definition of the RCSTS seems excessive with respect to the PDRD functional definition of the CSTS, the differences have no project impacts, and change to the current design baseline (FDC) would not be warranted based on the following. The RCSTS design incorporates some requirements that supports the Process Waste function currently identified by TWRS systems engineering. This includes the capability to pump slurry wastes and facilitate future connections to TWRS facilities. Although the requirements for the Process Waste function are under development, the RCSTS will likely provide the architecture that is capable of satisfying some of these processing requirements. These features offer operational flexibility by allowing for a wider range of waste to be transferred by the system other than just supernatants and will provide the capability to support other programs and their facilities in addition to meeting the functional requirements of the Interim Stabilization Program.

The PDRD functional definition states that for transferring managed tank waste, no conditioning or mobilization of the waste is required to accomplish this particular function. The PDRD, in fact, does levy waste physical characteristic constraints to interfacing systems that would allow for the pumping of slurry wastes also and not just supernatants in satisfying the functional definition for CSTS waste transfer. Dilution of a particular waste may be required to meet these system constraints to allow for pumping. 


\subsection{CROSS-SITE TRANSFER REQUIREMENTS}

\subsubsection{Waste Volume Requirements}

Volume requirements are needed to determine how robust the system and its components must be in order to support the defined mission for the CSTS. Volume requirements will differ depending on which portion of the cross-site transfer function will be addressed.

2.2.1.1 Total Waste Volumes - PDRD. The Cross-Site transfer system shall be capable of transferring a minimum of $9.59 \mathrm{Mgal}\left(3.63 \times 10^{7} \mathrm{~L}\right)$ of waste consisting of the following: $\begin{array}{lll}\text { PFP } & \text { Stabilization run } & 561 \mathrm{kgal}\left(2.12 \times 10^{6} \mathrm{~L}\right) \\ \text { Lab wastes } & 396 \mathrm{kgal}\left(1.50 \times 10^{6} \mathrm{~L}\right)\end{array}$

T-Plant $1.98 \mathrm{Mgal}\left(7.49 \times 10^{6} \mathrm{~L}\right)$

$222-S L a b$ $2.38 \mathrm{Mgal}\left(8.99 \times 10^{6} \mathrm{~L}\right)$

Saltwell Pumping (West Area) $3.58 \mathrm{Mgal}\left(1.36 \times 10^{7} \mathrm{~L}\right)^{2}$

Existing 241-SY-102 inventory Total volume: $691 \mathrm{kgal}\left(2.6 \times 10^{6} \mathrm{~L}\right)$

This volume results from the evaluation of the Operational Waste Volume Projection report (WHC, 1994a) and the Waste Tank Summary Report for Month Ending November 30,1994 (Hanlon, 1995). The volume listed here includes only pumpable liquid wastes not requiring conditioning or mobilization as per the definition outlined in the PDRD (see Section 2.1.1).

2.2.1.2 Total Waste Volumes - FDC. Each pipeline shall be capable of transporting liquid waste at the following flowrate and total capacity:

- Peak flow of 20 million gallons per year

- Total of 200 million gallons over the design life of the project

2.2.1.3 Total Waste Volumes Differences. The PDRD requirement for waste volumes results from summing the derived data from the Operational Waste Volume Projection report and the Monthly Waste Tank Summary Report. This is the volume of pumpable liquid waste that the transfer system must be capable of moving. This requirement is derived based on the defined mission of the cross-site transfer system outlined in Section 2.1.1.

The total volume arrived at for the FDC is based on the TWRS Process Flowsheet (WHC 1994b) which states "The retrieved volume of wastes is $5.95 \mathrm{X}$ $10^{6} \mathrm{~L}$ (157 Mgal)...". The volume indicated is the total volume anticipated to be retrieved and as such, has not been analyzed at lower levels (i.e., what fraction of this waste comes from the 200 West Area). The total volume outlined in the FDC represents the worst case total volume of retrieved wastes from the tanks with $25 \%$ contingency.

2 The transfer of 435,400 gallons of waste from $241-$ sY-102 to 241-AP-104 occurred on August 1 , 1995. 
The FDC flow rate requirement is based on the assumption that 20 tanks in 200 West will be retrieved within the same year, assuming tank capacities to be $1 \mathrm{Mgal}$ each. The milestones M-45-05-T13, M-45-05-T14, and M-45-05-T15 state that 20 additional SSTs are to be retrieved in the years 2015, 2016, and 2017, respectively, but do not distinguish which tanks are to be retrieved (whether in the 200 East Area or the 200 West Area or a combination of both). There are a total of 15 SSTs in the West Area with a capacity of $1 \mathrm{Mgal}$, with another 36 SSTs at $758 \mathrm{Kgal}, 24$ SSTs at $530 \mathrm{Kgal}$ and 8 SSTs at $55 \mathrm{Kgal}$ (these are capacities, not actual waste volumes). The 3 DSTs in the West Area have a capacity of $1.16 \mathrm{Mgal}$ each. The peak flow rate requirements for the CSTS must include projected wastes to be introduced to the staging tanks (West area DSTs) from terminal clean-out of west area facilities and the waste generated by $D \& D$ as required during peak years for SST retrieval.

Waste volumes to be managed within the tank farms have been projected out to the year 2005 and are documented in WHC-SD-WM-ER-029, Rev. 20. Data with respect to volumes of pumpable liquids remaining in the 200 West Area tanks and the liquid waste volume projected for the 200 West Area are summarized in Section 2.2.1.1 which support the mission outlined in Section 2.1.1. More waste may be coming into the tank farms from activities external to the Remediate Tank Waste function in the years beyond 2005 (e.g. T-Plant, 222-S (ab). This leaves uncertainty in total volume, waste physical, chemical, and radiological requirements for the cross-site transfer system. What is known is the total volume of pumpable liquid wastes to be managed within the 200 West tank farms.

In summary, the PDRD lists the minimum waste volume that the CSTS must be capable of transferring as $9.59 \mathrm{Mgal}\left(3.63 \times 10^{7} \mathrm{~L}\right)$ acknowledging that more waste is expected but firm numbers are not yet available. This volume is much smaller than the one currently used for CSTS design which is $200 \mathrm{Mgal}$ (7.57 $\mathrm{x}$ $\left.10^{8} \mathrm{~L}\right)$ which uses the volume anticipated upon completion of retrieval of a 11 tanks plus a contingency factor. The volume difference stated here is of little concern as the same system would be required to move both the $9.59 \mathrm{Mga} 1$ as the $200 \mathrm{Mgal}$ given the waste physical characteristics constraints for the CSTS.

2.2.1.4 Impacts to Project Resulting From Waste Volume Differences. By changing the design criteria to support only a waste volume movement of 9.59 Mgal as opposed to $200 \mathrm{Mgal}$ has little benefit given that design is near completion. Additional costs to change the design and a delay in the project schedule would be experienced and the flexibility of the system to handle additional waste volumes as well as higher peak flow rates would be lost.

\subsubsection{Shielding Requirements}

In order to incorporate ALARA principles into the CSTS design and to minimize radiation exposure to the occupational worker, shielding requirements have been developed for the CSTS.

2.2.2.1 Shielding Requirements - PDRD. Shielding design requirements for the cross-site transfer system outlined in the PDRD are based on the "worst case" radionuclide concentrations of the DST waste as documented in Double Shell Tank Farm Facility (241-AN, AW, AP, and SY) Safety Analysis Report (WHC, 1986). Sample analysis performed on "worst" case waste to be transferred from the SY-Farm to the waste storage facilities located in the 200 East Area 
WHC-SD-W058-RPT-002, Rev. 2

revealed radionuclide inventories below the inventory assumed in the Safety Analys is Report (Bergmann, 1990).

2.2.2.2 Shielding Requirements - FDC. The CSTS shielding design from the SY Tank Farm to the western boundary of proposed pretreatment/processing facility locations (location along CSTS where these facilities tie in) shall be based on the same radionuclide inventory concentrations referenced in Section 2.2.2.1. In addition, to support future east-to-west transfers of aging waste, shielding design from the proposed pretreatment/processing facility tie-in to the 244-A Lift Station shall be based on the radionuclide inventory concentrations from the $A Z$ Tank Farms. These are worst case radionuclide inventories for the 200 East Areas.

2.2.2.3 Shielding Requirements Differences. The PDRD defines the mission of the CSTS which is to move waste from the 200 West Area to the 200 East waste storage tanks. As such, the shielding requirements that have been levied on the CSTS design by the PDRD only incorporate worst case radionuclide concentrations of the waste in the West Area.

The current design has defined a portion of the system east of the proposed pretreatment/processing facility tie-in with more stringent shielding requirements due to worst case radionuclide inventories in the east area, namely the $A Z$ farms. This supports retrieval and pretreatment of aging wastes as well as other DSTs. Interface requirements from pretreatment programs or vitrification programs in terms of locations, type of waste to be received, waste physical, chemical and radiological characteristics, etc, are not yet adequately defined. Greater shielding requirements may be needed beyond what is known for the West Area wastes but only after facility locations are better defined and interfaces established with certainty.

Thus, in summary, the current design (per FDC) has a more stringent shielding requirement for the stretch of piping between the 244-A Lift Station and the proposed pretreatment/processing facility tie-in. This is to allow for the transfer of waste westward to the location on the pipeline which is in close proximity to the proposed pretreatment facility location. This would facilitate future connection of the RCSTS to this TWRS facility. The PDRD only requires shielding for worst case radionuclides seen in the west area as no definite pretreatment or processing requirements were found.

2.2.2.4 Impacts to Project Resulting From Shielding Difference. Although the PDRD calls for "less" shielding, the costs to remove the additional shielding already incorporated into the design may impact the cost and schedule of the project while these design changes took place. It would also remove the flexibility now provided by the system design to provide shielding for worst case East Area radionuclides that may be required to be transferred westward to these future TWRS facilities located at these proposed sites. Since the RCSTS is anticipated to support, to some measure, the future TWRS facilities, it stands to reason that the system should offer as much flexibility as requirements would allow.

\subsubsection{Design Life Requirements}

2.2.3.1 Design Life - PDRD. The cross-site transfer system shall be designed for a service life of approximately 7 years. The defined mission of the Cross-Site Transfer System is to support the transfer of pumpable liquid waste 
WHC-SD-W058-RPT-002, Rev. 2

from the 200 West Area staging tank 241-SY-102 (which receives its waste from SSTs and west area facilities) to the 200 East Area designated waste receiver tank.

2.2.3.2 Design Life - FDC. The piping in the cross-site transfer system shall be designed with a service life of 40 years. Components must be easily replaceable if they have a shorter design life. Components shall have the longest economically achievable design life.

2.2.3.3 Design Life Differences. The near term mission of the CSTS is to move pumpable liquid waste from 200 West to the 200 East Area to support the interim stabilization program and to move the projected waste volumes outlined in WHC-SD-WM-ER-029, Rev. 20, Operational Waste Volume Projections.

The interim stabilization program is scheduled to be completed with stabilization of all SSTs by September 30, 2000, TPA M-41-00, "Complete Single Shell Tank Interim Stabilization". The schedule for the terminal cleanout of existing west area facilities (S-Labs, T-Plant) extends out to the year 2005 with waste volumes projected up to that year. Also included in this time frame is the 241-SY-101 and 103 retrieval and the PFP Stabilization efforts. Based on these near term needs the design life of the CSTS is estimated to be approximately 7 years, given an operational start date of February of 1998, TPA Milestone M-43-07C, "Cross-Site Transfer System Operational".

Existing TPA milestones imply the need for longer design life for the movement of wastes between pretreatment, immobilization and waste storage facilities out to the year 2028 (TPA M-50-00, "Complete Pretreatment Processing of Hanford Tank Waste", 12/31/2028; TPA M-51-00, "Complete Vitrification of Hanford High Level Tank Waste", 12/31/2028; and TPA M-60-00, "Complete Vitrification of Hanford Low Level Tank Waste", 12/31/2028). This implies a design life of 30 years assuming a operational date of 1998 for the CSTS.

In summary, the design 1 ife required by the FDC is 40 years, anticipating the support of retrieval, pretreatment and vitrification programs while the design life specified by the PDRD is approximately 7 years, supporting only the transfer of waste volumes projected out to the year 2005.

2.2.3.4 Impacts to Project Resulting From Design Life Differences. The RCSTS has been designed in anticipation of supporting the retrieval, pretreatment and vitrification programs. Changing the design life requirement from 40 years to 7 years would exclude the CSTS from being a portion of the solution to TPA milestones that exist for pretreatment and vitrification. These milestones are to be completed by the year 2028 and it is anticipated that the CSTS will have a role in supporting these programs. The current design is near completion and increased costs and a delay in the project schedule could be expected to implement this change. The flexibility of the system would a) so be compromised by shortening the design life requirement.

\subsubsection{PDRD Requirements Not Included in FDC}

This section describes the additional requirements specifically listed in the PDRD but not specifically listed or described in the FDC. The specifics of these requirements are addressed by other project documentation and general design criteria documents called out in the FDC. In the case of 
maintenance of the system, the FDC requires that remote maintenance be incorporated into the design where possible. Decontamination and decommissioning of CSTS components is addressed by the FDC. The FDC requires that solid waste packaging, storage, and disposal be in accordance with WHCEP-0063 which is a document that references WHC-CM-2-14 as a source document. The latter document and its requirements is the one called out by the PDRD.

In some cases, the PORD requirement is not definitive, but has a required analysis associated with it. This required analysis may be necessary in order to arrive at definitive performance requirements for the PDRD which can then be imposed on the CSTS design.

2.2.4.1 Mean Time Between Failure. The cross-site transfer system shall be designed for a reliability such that the mean time between failure (MTBF) is TBD. An analysis must be done in order to determine the risk and impacts to the overall tank farm operations in the event of CSTS failure. This analysis should consider the safety classification of the CSTS and its components. Quantification of the risks and impacts shall be translated into MTBF values for the cross-site transfer system as a whole as well as its system elements.

2.2.4.2 Availability. The Cross-Site Transfer System shall be available to perform cross-site transfers $2 \%$ (based on total volume of $9.59 \mathrm{Mgal}$ to be moved over 7 years) of the time throughout its design life. The system avallability requirement is an estimate based on yearly peak flow rate of 1.37 Mgal/yr with an average volumetric flow rate of $140 \mathrm{gpm}$ over that year. As the analysis of the total waste volume to be transferred cross-site is refined, the system availability shall also be refined in order to meet the overall program needs for transfer of wastes cross-site.

2.2.4.3 Excess Facilities Interface Requirements. The cross-site transfer system elements shall meet the interface requirements set forth by the site level function 4.1, Deactivate Facilities. An analysis is needed that determines the appropriate acceptance criteria for transfer of excess facilities to the facilities/agencies performing the site-level Deactivate Facilities function (4.1). The requirements associated with the site level Deactivate Facilities function are currently under development and will be levied appropriately to other functions. Design requirements and design features can then be implemented to ensure the cross-site transfer system elements are amenable for turn-over, at the end of their design 1ife, to the facilities performing function 4.1 . The cross-site transfer system design will incorporate design features that support disposal of solid waste and decontamination and decommissioning of the system.

2.2.4.4 Maintenance. Remote, limited or contact maintenance and operation shall be in accordance with the following radiation contact exposure threshold values.

2.2.4.4.1 Fully Remote Maintenance and 0peration. Each system or portion of the system having radiation levels greater than $50 \mathrm{mrem} / \mathrm{hr}$ contact exposure shall be designed to be remotely maintained and operated or designed to require no maintenance and be remotely operated.

2.2.4.4.2 Limited Contact Maintenance and Operation. Each system or portion of a system having radiation levels greater than $0.25 \mathrm{mrem} / \mathrm{hr}$ to less than or equal to $50 \mathrm{mrem} / \mathrm{hr}$ shall be designed for limited contact maintenance and 
operation. Designs shall consider remote removal of radiation sources and decontamination prior to personnel entry.

2.2.4.4.3 Full Contact Maintenance and Operation. Each system or portion of a system having radiation levels less than or equal to $0.25 \mathrm{mrem} / \mathrm{hr}$ shall be designed for full contact maintenance and operation.

2.2.4.5 Transportation of Hazardous Materials. The cross-site transfer system elements shall be designed to be handled, packaged, marked and transported in accordance with WHC-CM-2-14 "Hazardous Materials Packaging and Shipping" so that cross-site transfer system elements can be appropriately transported following usage (e.g., to maintenance depots, to deactivation facilities at the end of their design 1 ife, etc.). 
WHC-SD-W058-RPT-002, Rev. 2

This page intentionally left blank. 
WHC-SD-W058-RPT-002, Rev. 2

\subsection{EXISTING SYSTEM INTERFACE}

This section defines architecture that is either in place or will be provided that will help satisfy the overall CSTS function.

\subsection{CURRENT SCOPE OF $\mathrm{W}-058$}

The scope of Project $W-058$ as defined by the Project FDC is to provide a replacement piping system for the existing cross-site transfer system. The system shall consist of a pipe-in-pipe system connecting the 241-SY Tank Farm 241-SY-A and $-B$ valve boxes with the 244-A Lift Station. Figure 3.1-1 outlines the current scope of the RCSTS.

The function Transfer SY-Farm Liquid Waste Cross-Site is defined as "The recovery and transfer of pumpable liquid waste requiring no mobilization or conditioning cross-site from one storage location to a designated receiver tank". Project $W-058$ accomplishes a portion of the function by replacing the pipeline between the SY valve boxes and the 244-A Lift Station as described in the preceding paragraph. Additiona $11 y$, Project $W-058$ provides some capability to support future retrieval and processing activities by providing a system which can pump slurries. It also has features in the design which allow for future diversion box $p l a c e m e n t$ in certain areas along the cross-site transfer system line which would facilitate connection to these future TWRS facilities requiring access to the CSTS.

\subsection{OTHER PROJECTS/EXISTING ARCHITECTURES}

\subsubsection{Tank Farms Restoration and Safe Operations, W-314}

The Project $W-314$, Tank Farms Restoration and Safe Operations, PDRD has identified requirements to provide safety upgrades to waste transfer systems within the A-Farm complex. These requirements will cover all upgrades to waste transfer systems (including the A-Farm Complex) which other projects do not provide. The project interface control documents for $W-314$ indicate that studies are underway to determine whether upgrade costs for 244-A can be justified or if providing an alternative solution to the interface with the new cross-site transfer system would be a preferable alternative (WHC, 1995c). Project W-058 will terminate at the 244-A Lift Station and will gain access to the 200 East Tank Farms via this facility. Further definition of the interface between Project $W-314$ and $W-058$ is needed such that $W-058$ can provide the appropriate interface to $W-314$ as the requirements develop.

\subsubsection{SY-Farm Existing Architecture}

3.2.2.1 Transfer System. Part of the function of the cross-site transfer system as defined in Section 3.1 is to recover the pumpable liquid waste in the storage facilities. Existing architecture (pipelines, pumps, etc.) between the 241-SY-Farm valve boxes and the 241-SY pump pit will serve to recover, contain and move the waste from the 241-SY-102 tank to the 241-SY-A \& $B$ valve boxes. Waste transfer will be initiated by using the transfer pump in pump pit 241-SY-02A. Waste will then be pumped through a three inch pipeline, 
SN-285, to the 241-SY valve boxes where it will be routed into Project $W-058$ architecture.

Project $W-211$, Initial Tank Retrieval Systems, is planning to upgrade the transfer pump to bring it into compliance with the interface requirements for fluid velocity and net positive suction head to the RCSTS booster pump by 1999. The current system must be evaluated to ensure it can meet these interface requirements in the interim.

3.2.2.2 Flushing System. The Cross-Site Transfer System design provides a backup flushing system to be used in emergency situations. The existing flush water system located in the SY-Farm will be used to supply flush water for normal operational flushes to the cross-site transfer system at the 241-SY-A \& $B$ valve pits. Interface requirements for the flush water system include minimum $\mathrm{pH}$ of 11 , temperature between $35^{\circ} \mathrm{F}$ and $200^{\circ} \mathrm{F}$. Originally, Project $W-$ 211 was to provide upgrades of the flushing system to meet the CSTS needs. Evaluations must be performed to ensure that the existing flush water system is adequate to meet the interface requirements set forth by the CSTS. 
WHC-SD-W058-RPT-002, Rev. 2

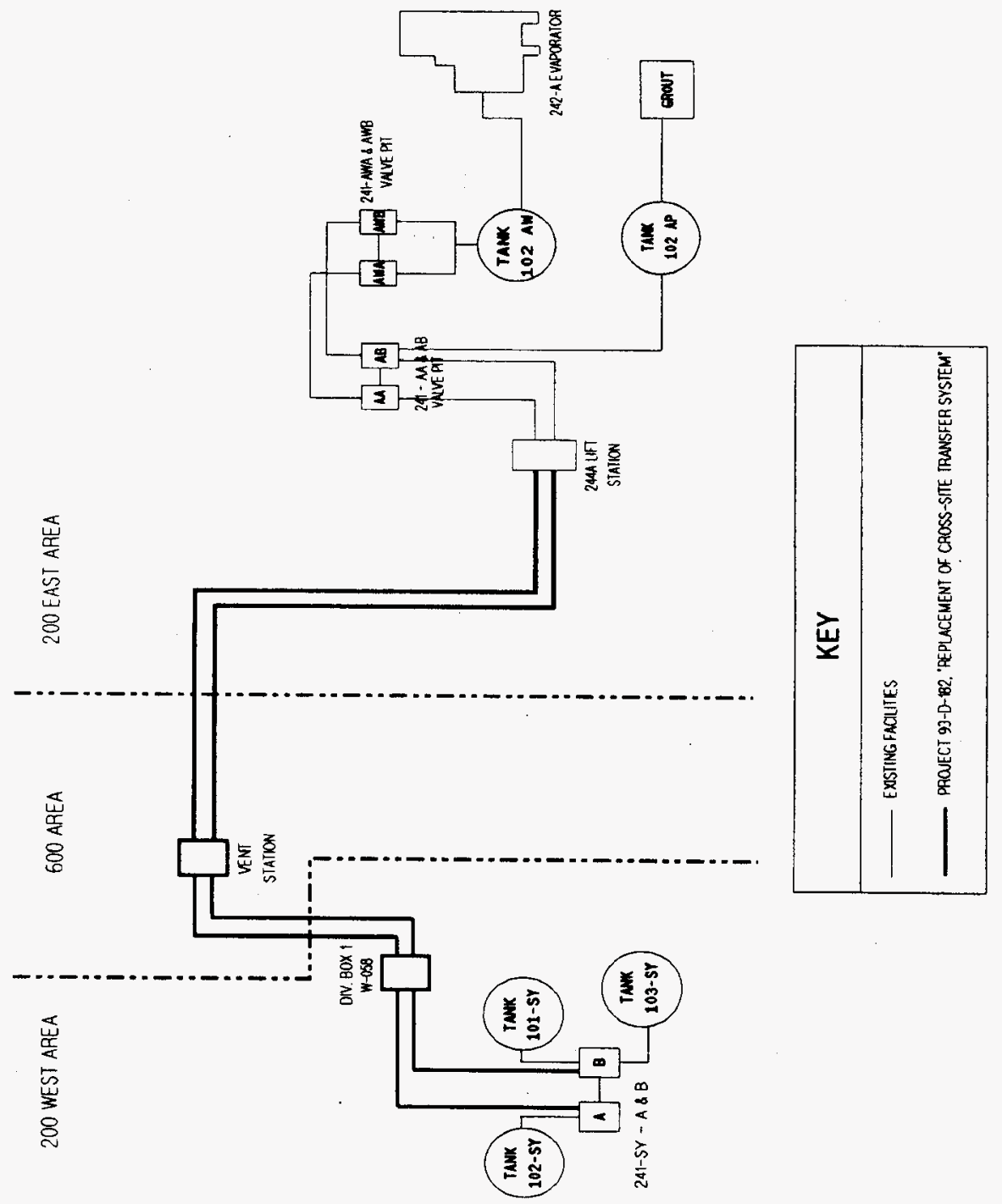

FIGURE 3.1-1 Current Scope - Project W-058 
WHC-SD-W058-RPT-002, Rev, 2

This page intentionally left blank. 
WHC-SD-W058-RPT-002, Rev. 2

\subsection{CONCLUSIONS}

The CSTS has a defined mission of supporting the management of tank waste and will likely support the retrieval and processing of this waste as part of a future mission role. Although the systems engineering effort has not progressed to the point of allocating definitive waste retrieval processing performance requirements to the CSTS design, design features to support processing of the waste can be justified and were previously incorporated into the CSTS design. A comparison of the CSTS design specifications to the design requirements outlined in the project PDRD reveals that the design specs meet and/or exceed the requirements currently known for transferring Managed Tank Waste. Requirements on waste processing (although not yet derived by TWRS SE) may result from the TWRS Privatization Request for Proposal (RFP) which outlines constraints on pipeline transfers in Section C, Part 3, Specification 9.0, Liquids or Slurries Transferred to DOE by Pipeline or Liquid Transport Cask. A preliminary review of this specification shows that the CSTS design will accommodate the requirements to be imposed on the waste physical properties listed in the RFP.

The existing system has a poor reliability (approx. $2.8 \%$ for a single existing line) over a ten year 7 ife and is not adequate in serving the needs for either of the previously described missions. Options have been evaluated to determine what architecture would best satisfy the cross-site transfer mission. A comparative cost analysis was performed and revealed that replacement of the existing cross-site transfer system was the preferred a) ternative over truck or rail transfer of the wastes (Riesenweber, 1995b). This analysis showed that the preferred alternative was the most cost effective in meeting the TWRS long-term transfer needs.

With the CSTS design already near completion, the risks would be high and the vision short sighted to modify the existing design to support only the manage tank waste portion of the mission. Changing the design criteria to support only a waste volume movement of $9.59 \mathrm{Mgal}$ as opposed to $200 \mathrm{Mgal}$ has little benefit. The same system would be required to move both the 9.59 Mgal as the $200 \mathrm{Mgal}$ given the waste physical characteristics constraints for the CSTS. Similarly, changing the design life requirement from 40 years to 7 years would simply ignore the fact that TPA milestones exist for pretreatment and vitrification to be complete by the year 2028 and it is anticipated that the CSTS will have a role in supporting these programs. The design has also incorporated additional shielding requirements for "worst" case" radionuclides in the East Area for east to west transfers in anticipation of support of the pretreatment and vitrification facilities thereby increasing the system's flexibility.

The additional requirements that were documented in the PDRD and the associated required analyses may not be warranted based on the current project status, the time constraints associated with the TPA, and the additional cost to perform these analyses and to change the design. Specifically, the MTBF and availability requirements and their concerns called out in the PDRD are addressed by the existing design's reliability. The Excess Facilities Interface requirements and the Transportation of Hazardous Materials requirements called out in the PDRD are addressed by the requirements called out in the FDC for decontamination and decommissioning and solid waste packaging, storage, and disposal per WHC-EP-0063. The requirements for remote 
maintenance are more conservative by the FDC criteria based on requirement "the design shall consider minimizing hands on contact maintenance" and thus a change to the PDRD requirements set is not warranted.

The existing components at the 241-SY tank farm which support the crosssite transfer system (i.e., the 24l-SY transfer pump and the existing flush water system) require further evaluation of their capabilities to meet the imposed interface requirements to ensure that the transfer of waste can be accomplished from 24l-SY-102 to the designated receiver tank.

The baseline comparison between the project FDC and the PDRD did reveal some significant functional and requirements differences. These differences, after evaluated, posed little to no impacts on the current CSTS design and, therefore, change to the existing baseline is not warranted. 
WHC-SD-W058-RPT-002, Rev. 2

This page intentionally left blank. 
WHC-SD-W058-RPT-002, Rev. 2

\subsection{REFERENCES}

ARES, 1994, Cross-Site Transfer System WHC Projects W-058/028 Reliability Analysis of CSTS Pipelines, Report No. 931101-004, June 9, 1994, prepared for the Westinghouse Hanford Company, Richland, Washington.

Bergmann, L. M., Source Term and Minimum Pipe Shielding Requirement W-058, WHC Internal Memo \#82331-90-179, dated Apri1 20, 1990, from L.M. Bergmann to C.C. Cejka, Westinghouse Hanford Company, Richland, Washington.

Coles, G.A., Risk and Reliability Information About the Cross-Site Transfer System, WHC Internal Memo \#GAC-8M400-95-002, dated August 29, 1995, from G.A. Coles to S.D. Riesenweber, Westinghouse Hanford Company, Richland, Washington.

DOE, 1987, Project Management System, DOE Order 4700.1, U.S. Department of Energy, Washington, D.C.

DOE, 1988, Radioactive Waste Management, DOE Order 5820.2A, U.S. Department of Energy, Washington, D.C.

DOE/RL, 1992, DNFSB Recommendation 92-4 Implementation Plan, DOE/RL-94-115, Rev. 1, U.S. Department of Energy, Richland, Washington.

D0E/RL, 1994, Tank Waste Remediation System Functions and Requirements, DOE/RL-92-60, Rev. 1, U.S. Department of Energy, Richland, Washington.

DOE/RL, 1995, Tank Waste Remediation Systems Engineering Standard, D0E/RL-9512, Rev. AE, Draft, U.S. Department of Energy, Richland, Washington.

Ecology, EPA, and DOE, 1994, Hanford Federal Facility Agreement and Consent Order, as amended, Washington State Department of Ecology, U.S.

Environmental Protection Agency, and the U.S. Department of Energy, 01 ympia, Washington.

Evans, R. A., 1994, Radiological Design Guide, WHC-SD-GN-DGS-30011, Rev. O, Westinghouse Hanford Company, Richland, Washington.

Hanlon, B. M., 1995, Waste Tank Summary For Month Ending November 30, 1994 , WHC-EP-0182-80, Westinghouse Hanford Company, Richland, Washington.

Peck, L. G., Format for Design Requirements Documents (DRD), WHC Internal Memo, dated January 20, 1995, from TWRS Systems Integration to Distribution, Westinghouse Hanford Company, Richland, Washington.

Riesenweber, S. D., 1995a, Project W-058 Path Forward, Interoffice Memorandum Letter \#9553354, dated June 27, 1995, J. L. Lee, Director Tank Farms Transition Projects, WHC to A. B. Sidpara, Director Tank Operations Division, DOE. 
Riesenweber, S. D., 1995b, Comparative Cost Analysis for Support of the Environmental Impact Statement Safe Interim Storage of Hanford Tank Wastes Record of Decision Deliverable, Letter \# 9504812B Rl, Dated November 10, 1995, James H. Wicks, Tank Farms Transition Projects, WHC to C. P. Bader, Director Program Integration Division, DOE.

WHC, 1986, Double Shell Tank Farm Facility (241-AN, AW, AP, and SY) Safety Analysis Report, WHC-SD-WM-SAR-016, Rev. 1, Westinghouse Hanford Company, Richland, Washington.

WHC, 1988, Hanford Radioactive Solid Waste Packaging, Storage, and Disposa7 Requirements, WHC-EP-0063, Westinghouse Hanford Company, Richland, Washington.

WHC, 1990, Engineering Study for Replacement of the Cross-Site Transfer System, WHC-SD-W058-ES-001, Rev. 0, Westinghouse Hanford Company, Richland, Washington.

WHC, 1994a, Operational Waste Volume Projection, WHC-SD-WM-ER-029, Rev. 20, Westinghouse Hanford Company, Richland, Washington.

WHC, 1994b, TWRS Process Flowsheet, WHC-SD-WM-TI-613, Rev. 0, Westinghouse Hanford Company, Richland, Washington.

WHC, 1994C, Hanford Site Radiological Control Guide, HSRCM-1, Rev. 2, West inghouse Hanford Company, Richland, Washington.

WHC, 1995a, Functional Design Criteria for Project W-058, Replacement of the Cross-Site Transfer System, WHC-SD-W058-FDC-001, Rev. 3, Westinghouse Hanford Company, Richland, Washington.

WHC, 1995b, Preliminary Design Requirements Document for Project W-058, Replacement of the Cross-Site Transfer System, WHC-SD-W058-DRD-001, Rev. 0, Westinghouse Hanford Company, Richland, Washington.

WHC, 1995c, Preliminary Design Requirements Document for Project W-314, WHCSD-W314-DRD-001, Rev. 0, Westinghouse Hanford Company, Richland, Washington. 


\section{DISTRIBUTION SHEET}

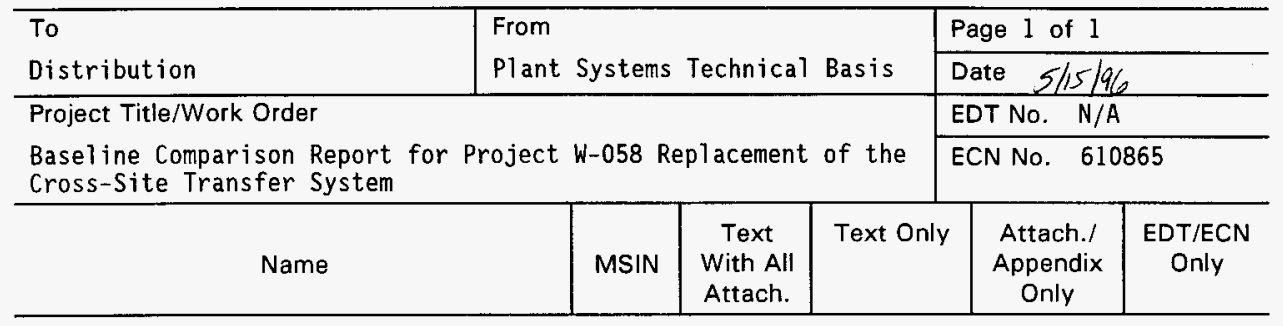

U.S. Department of Energy, Richland Operations Office

J.M. Clark

B.J. Harp

Westinghouse Hanford Company

N.G. Awadalla

J.L. Gilbert

J.P. Harris

J.L. Homan

S.C. Kl imper

D.P. Mendoza

G.L. Parsons

W.W. Rutherford

M.J. Sutey

Project Files

Central Files

\section{S7-54}

S7-54

$\begin{array}{ll}\text { H6-35 } & X \\ \text { B4-08 } & X \\ \text { S2-48 } & X \\ \text { H5-09 } & X \\ \text { H6-35 } & X \\ \text { H5-09 } & X \\ \text { B4-08 } & X \\ \text { R3-25 } & X \\ \text { T4-07 } & X \\ & \text { X5-05 } \\ \text { A3-88 } & X \\ & X\end{array}$

